\title{
COMMENT
}

\section{Anti-Black racism in academia and what you can do about it}

\author{
Audrey K. Bowden $\mathbb{1}^{1 凶 \text { and Cullen R. Buie }}{ }^{2}$
}

The experiences of Black scientists and engineers reveal that science is not a meritocracy. Here is a list of recommendations to combat anti-Black racism in academic institutions.

Racism is an insidious, multifarious social disease. Like cancer, most people do not perceive any issues until there is a catastrophic eruption, such as protesting in the streets over the murder of a Black person by the police. Increasingly, many people claim to be 'woke' to the idea of anti-racism; however, combatting anti-Black racism requires more than broad-sweeping 'diversity, equity and inclusion' rhetoric - a profound change in the mindset, attitudes and actions of every individual in society is needed, including you.

\section{The experience of Black scholars}

The academic community is not immune to society's racial challenges. Our experiences as scholars cannot be decoupled from our Black identities ${ }^{1}$. Thoughts about how to stay safe, in a society in which violence against our bodies and our minds is a real threat, give rise to fears (The Fear Black Employees Carry) that affect our interactions at conferences and on campuses. We personally recall with disgust being racially profiled by hotel security at a scientific conference; being stopped, detailed and questioned for an hour by the police after a long evening of studying at the campus library; and being questioned about the legitimacy of our presence in faculty clubs and on-campus residences. Unfortunately, our experiences are neither unique nor uncommon (Santa Clara University launches investigation after a Black professor was asked by campus security to prove she lived in her own house). We have had to learn the hard way how to navigate the unspoken rules of academia, finding our own way into study groups as graduate students or academic collaborations as principal investigators. Some Black peers struggle to master these informal systems, ultimately not completing their PhDs or getting tenure, reinforcing the stereotype that Black scientists are less qualified and making it more difficult for Black scholars to climb through the ranks and thus perpetuating the cycle. Some Black colleagues worry that stereotypes and biased practices keep them from getting published, winning grants, or advancing in their careers despite equal qualifications $s^{2,3}$. Truth be told, having to work harder to obtain similar opportunities to our colleagues takes an emotional toll ${ }^{4,5}$. We are tired.

\section{The racialization of academia}

Practices such as creating homework assignments that require students to self-organize into groups, making admissions or hiring decisions based on academic pedigree, or judging articles and proposals on the perceived 'merit' of the investigator rather than on the scientific idea are not overtly racist, but their outcomes perpetuate the racialization of academia. That is, one does not need explicitly racist policies to yield racial disparities; it is perhaps more accurate to describe our academic and scientific organizations as racialized rather than racist $^{6}$. If the working definition of racism only considers activities or policies that explicitly discriminate on the basis of race, it is easy to believe that racism does not exist. Yet, like many diseases that quietly invade the body, anti-Black racism has metastasized beneath the surface in the form of goods, benefits and services that are disproportionately allocated along the lines of race, invading the culture of how society operates. For example, providing grant supplements only to those with active awards is not openly racist; however, when you consider that Black principal investigators are funded at a much lower rate than their white colleagues ${ }^{7,8}$, the result is less access for Black researchers to these funding opportunities. Similarly, while most hiring policies prevent discrimination on the basis of race, employment is often linked to social networks within an institution. When you consider that fewer Black people have historically been in positions of power at scientific institutions, the result is an inequity of opportunity.

\section{Call to action}

Society likes to tout that science is a meritocracy, but science is not a meritocracy because the world is not a meritocracy. Resources, services and benefits allocated within the academic and scientific communities are strongly influenced by race, whether you see it or not. If you are serious about combatting anti-Black racism within your institution, we refer you to the list of recommendations outlined in the Call to action proposed by the organization Black in Engineering, a group of faculty comprising all ranks and types of institution within the USA. Of supreme importance is to approach 
the document and the task of transformation with an intention - dare we suggest a formal commitment - to act. The Call to action offers several principles to invoke this commitment; here we cite a few of its salient points.

Attitude. Assume you and your institution have a problem. The Black people around you have been saying it for decades; it is time to listen. If you do not think you have a problem, you are more likely to dismiss suggestions as being irrelevant. Instead, identify aspects of your institution's policies and structures that are routinely overlooked as being racialized or contributing to racism. How many of your institution's hires tried to leverage their network to get a job? How diverse was the line-up of your last speaker series, and how were invitees selected (that is, are your people only inviting speakers in their current networks)? If your answers suggest an inequity of opportunity in the way you do things, do something about it.

Accountability. You must hold yourself and your institution accountable. There is little hope for change if there are no consequences for maintaining the status quo or blaming external circumstances, such as a small candidate pool. Do not blame the leaky pipeline - do your part to plug the leaks and prime the pump. We have all seen our institutions enact monumental changes when threatened with the existential crisis of COVID-19. Put that same intensity into adopting new strategies to improve the climate for Black scholars at your institution. Make a bold, public statement that puts your reputation on the line. Tie the need for change to the job description of someone whose compensation depends on enacting change, then set them up to succeed with substantial support from the highest leaders in the organization. Do not overlook that institutional change must include a change in you. Embrace new opportunities to reveal and unlearn your personal biases.

Committed leadership. If the most senior administrators are not committed to fundamental change, it is unlikely that progress made by concerned individuals will ever get institutionalized. Have the most senior person at your institution issue a statement that communicates commitment to change at every level. When necessary, rethink who your leaders are and how they are selected. Make sure that senior leaders are aware that change is coming and that they are on board. Communicate this message not just in value statements but in evaluation processes that reflect the degree to which actions match words. Celebrate success in ways that incentivize others to follow. Most importantly, do not make the few Black people already in your institution do all the work.

Resources. Moving the needle on anti-Black racism will be costly, and that should be expected. The toll that antiBlack racism takes on Black people is tremendous, and real justice demands a comparable investment. Do not implement changes that do not cost you anything - an unwillingness to spend money communicates that you do not value the work. Do not wait until you can raise money for new initiatives. Instead, rebalance your current budget to carve out funding. Make the resources available to existing committees that you have underresourced to take immediate action, or hold contests to crowdsource the best ideas of how to make impactful change. Once you have the ball rolling, it will be easier to raise new funding.

Resilience and creativity. Let's be honest: when you encounter a research setback, you do not simply throw up your hands in defeat. You redouble your efforts and employ all of your mental faculties to find a solution. The same level of commitment and ingenuity is required to battle anti-Black racism. If you are not in it for the long haul, you should seriously consider not getting involved at all. The more intellectual merit you think you have, the better you should be at coming up with good ideas or recognizing that it may be wise to hire guides who can shepherd your institution in this process.

Urgency. The time to act is now, and we are waiting. Here is an easy first step: identify what Black staff, faculty or student can you acknowledge, applaud or reward this week for their contributions in building and improving the cultural climate at your institution, then do it.

\section{If you are not part of the solution...}

You are the problem. Society likes to believe that the problem of racism will go away with time. History tells a different story; racial progress typically follows on the heels of intense struggle. There is no progress without struggle. Justice takes work - so get to it. Black lives won't matter in science until they matter to you.

1. Platt, M. O. We exist. We are your peers. Nat. Rev. Mater. 5, 783-784 (2020).

2. Bertrand, M. \& Mullainathan, S. Are Emily and Greg more employable than Lakisha and Jamal? A field experiment on labor market discrimination. Am. Econ. Rev. 94, 991-1013 (2004).

3. Desai, T. A., Eniola-Adefeso, O., Stevens, K. R., Vazquez, M. \& Imoukhuede, P. Perspectives on disparities in scientific visibility. Nat. Rev. Mater. 6, 556-559 (2021).

4. Clark, R., Anderson, N. B., Clark, V. R. \& Williams, D. R. Racism as a stressor for African Americans: a biopsychosocial model. Am. Psychol. 54, 805-816 (1999).

5. Lee, D. B. et al. Psychological pathways from racial discrimination to cortisol in African American males and females. J. Behav. Med. 41, 208-220 (2018).

6. Bonilla-Silva, E. Rethinking racism: toward a structural interpretation Am. Sociol. Rev. 62, 465-480 (1997).

7. Hoppe, T. A. et al. Topic choice contributes to the lower rate of NIH awards to African-American/black scientists. Sci. Adv. 5, eaaw7238 (2019).

8. Stevens, K. R. et al. Fund Black scientists. Cell 184, 561-565 (2021).

Competing interests

The authors have no competing interests.

RELATED LINKS
Black in Engineering: https://blackinengineering.org/
Call to action: https://blackinengineering.org/action-item-list//
Santa Clara University launches investigation after a Black professor was
asked by campus security to prove she lived in her own house: https://
edition.cnn.com/2020/08/24/us/santa-clara-university-black-professor-
campus-security-trnd/index.html
The Fear Black Employees Carry: https://hbr.org/2021/04/the-fear-black-
employees-carry

